\title{
Embedded fingernail in the gingival sulcus of a boy
}

\author{
Daffer Ghanim, ${ }^{1}$ Sean R Llewellyn, ${ }^{1}$ Morteza Khodaee (1) ${ }^{2}$
}

${ }^{1}$ Family Medicine, University of Colorado Denver School of Medicine, Denver, Colorado, USA

${ }^{2}$ Family Medicine and Orthopedics, University of Colorado Denver School of Medicine, Denver, Colorado, USA

\section{Correspondence to} Professor Morteza Khodaee; morteza.khodaee@ucdenver. edu

Accepted 21 May 2020

\section{DESCRIPTION}

A 10-year-old healthy boy presented with an uncomfortable sensation in his mouth. He admitted that he was biting his fingernails and felt his fingernail 'got stuck'. Parent of the child reported that patient having an occasional history of nail biting with no history of any medical or mental illness. On physical examination, there was an area of 'off white' colour and extra tissue on the lingual aspect of the gingival sulcus (figure 1). The fingernail was removed using a McKesson Adson tissue forceps without using anaesthetics (figure 2). The patient tolerated the procedure well without any immediate complications.

Fingernail biting is a common habit among children. It may or may not be associated with fingernail eating (onychophagia) that is a form of pica. Prevalence of fingernail biting has been estimated to be $12 \%-45 \%$ in children and $6 \%-60 \%$ in the general population. ${ }^{1}$ It starts as early as 4 years of age and reaches peak prevalence between the age of 10-18 years, with being more common

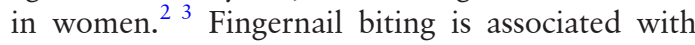
psychosocial conditions such as anxiety, attention deficit hyperactivity disorder (ADHD), obsessive compulsive disorder (OCD) and emotional stress. ${ }^{4}$ Fingernail biting is similar to behaviours such as habitual hair twirling, fidgeting, finger sucking, cheek, lip and finger biting. It has also been potentially linked to attention-seeking behaviour from parents or even a health professional. ${ }^{235}$ Although fingernail biting is prevalent, there are limited reports on the diagnosis and treatment of fingernail biting injuries. ${ }^{3}$ Fingernail biting is associated with complications such as local tissue injury, infections, systemic disease (eg, periodontal injury, gingival abscess formation and bacterial endocarditis) and bezoar. ${ }^{4}$ Local damage may be due to injuring the

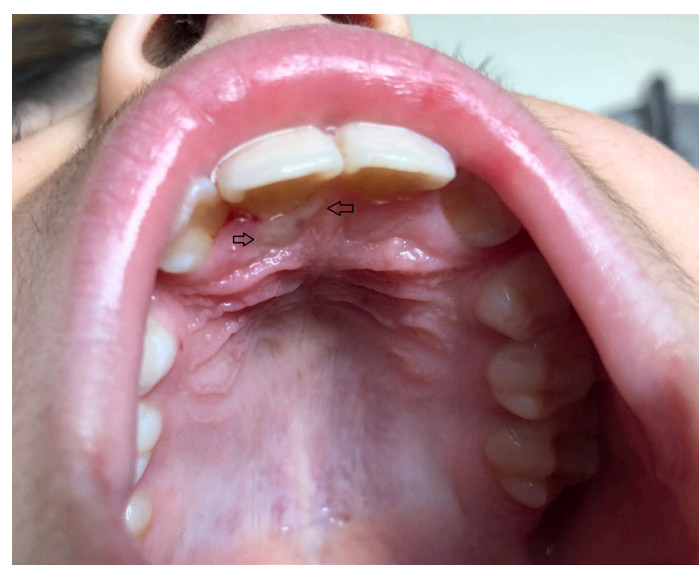

Figure 1 Impacted a fingernail (open arrows) in the lingual gingival sulcus posterior to the incisors.

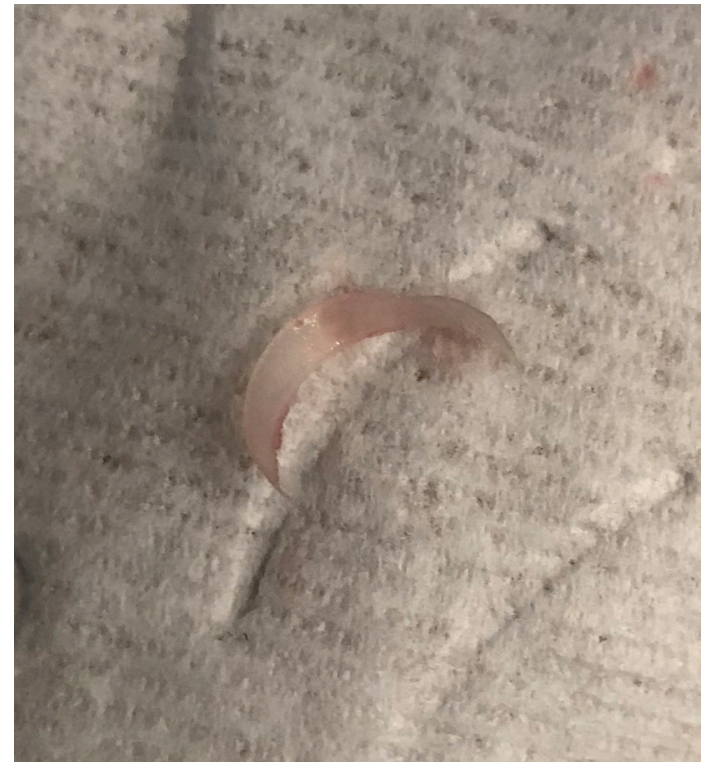

Figure 2 The impacted fingernail after removal from the lingual gingival sulcus.

gingival mucosa or, as in our case, due to a foreign object (ie, the actual nail) embedded in the gingiva. The injury is not always limited to the soft tissue, and in more severe cases may damage bone or tooth structure, loosening a tooth, teeth abrasion as well as possible malocclusion. In our case, the injury was limited to the gingival mucosa.

A comprehensive dental history and history of insertion of oral foreign objects are vital in cases of gingival injury or infection secondary to fingernail biting, which could obtain subtle information related to the injury. If unable to visualise a nail or foreign object, the provider may consider ordering dental imaging. A dental radiograph is only useful in locating objects that are radiopaque such as stapler pins, metal screws, darning needles and pencil leads. ${ }^{6}$ Fingernails are not visualised with plain radiography. In cases of radiolucent objects and a high suspicion of a foreign object impaction, a thorough visual inspection is a key to diagnosis. This should include evaluation of the full dentition, gums, oral cavity, nails and nail beds looking for possible signs of trauma due to fingernail biting.

Given that this habit could have underlying psychological bases, it is common for children to return to the office with recurrence of more nail fragment impactions, even after initial removal and advice to stop this habit. One recommendation is to have monthly visits for oral examination until the provider is confident the habit is resolved. ${ }^{23}$ If the habit is not controlled, a multidisciplinary treatment approach with the primary care provider, a dentist and a behavioural health provider is recommended 
to avoid impairment in the social and psychological developments of the child. ${ }^{2}$

\section{Patient's perspective}

This was a scary experience that made me stop my fingernail biting habit.

\section{Learning points}

- Consider fingernail biting in young children and adolescents presenting with gingival swelling or injury.

- Treatment of nail impaction includes mechanical removal of the foreign object, oral hygiene instructions, psychological support, possible dental referral and close follow-up to monitor reoccurrence.

- Due to possible underlying psychological behavioural issues, a multidisciplinary team approach including the primary care physician, dentist and behavioural health specialist is needed to manage children with persistent fingernail biting habit.
Contributors DG, SRL and MK participated in the literature review, manuscript preparation, review and approval.

Funding The authors have not declared a specific grant for this research from any funding agency in the public, commercial or not-for-profit sectors.

Competing interests None declared.

Patient consent for publication Parental/guardian consent obtained.

Provenance and peer review Not commissioned; externally peer reviewed.

\section{ORCID iD}

Morteza Khodaee http://orcid.org/0000-0003-3549-5333

\section{REFERENCES}

1 Creath CJ, Steinmetz S, Roebuck R. A case report. gingival swelling due to a fingernailbiting habit. J Am Dent Assoc 1995;126:1019-21.

2 Krejci CB. Self-Inflicted gingival injury due to habitual fingernail biting. J Periodontol 2000;71:1029-31.

3 Dilsiz A, Aydin T. Self-inflicted gingival injury due to habitual fingernail scratching: a case report with a 1-year follow up. Eur J Dent 2009;3:150-4.

4 Sousa D, Pinto D, Araújo R, et al. Gingival abscess due to an unusual nail-biting habit: a case report. J Contemp Dent Pract 2010;11:85-91.

5 Johnson CD, Matt MK, Dennison D, et al. Preventing factitious gingival injury in an autistic patient. J Am Dent Assoc 1996;127:244-7.

6 Passi S, Sharma N. Unusual foreign bodies in the orofacial region. Case Rep Dent 2012;2012:191873.

Copyright 2020 BMJ Publishing Group. All rights reserved. For permission to reuse any of this content visit

https://www.bmj.com/company/products-services/rights-and-licensing/permissions/

BMJ Case Report Fellows may re-use this article for personal use and teaching without any further permission.

Become a Fellow of BMJ Case Reports today and you can:

- Submit as many cases as you like

- Enjoy fast sympathetic peer review and rapid publication of accepted articles

- Access all the published articles

- Re-use any of the published material for personal use and teaching without further permission

\section{Customer Service}

If you have any further queries about your subscription, please contact our customer services team on +44 (0) 2071111105 or via email at support@bmj.com.

Visit casereports.bmj.com for more articles like this and to become a Fellow 